\title{
GEGERA BUDAYA DALAM ADAPTASI KEBIASAAN BARU (ABK) (KOMUNIKASI LINTAS BUDAYA WARGA GRAHA RANCAMANYAR DALAM MENGHADAPI PANDEMI COVID 19)
}

\author{
Suhaeri \\ Universitas Kebangsaan \\ Email: hery020370@gmail.com
}

\begin{abstract}
Abstrak
Perubahan kebiasaan merupakan bukan hal yang mudah untuk dilaksanakan terutama kebiasaan yang memang belum pernah sama sekali dihadapi.Fenomena tersebut dikenal dengan fenomena gegar budaya (culture shock), umumnya feneomena ini dijumpai pada seseorang yang baru merasakan kebiasaan atau budaya baru terutama bagi yang tinggal di luar daerahnya seperti di luar negeri/negara asing. Akan tetapi, fenomena ini juga dapat kita jumpai di lingkungan sekitar kita terutama pada masa pandemi covid-19 ini.Adanya pandemi covid-19 menjadikan segala kehidupan dunia berubah drastis.Adaptasi Kebiasaan Baru (AKB) diberlakukan sehingga segala sesuatunya harus mengikuti peraturan atau kebiasaan yang diluar kebisaan sebelumnya. Bahkan di beberapa daerah pemerintah setempat menerapkan PSBB (Pembatasan Sosial Berskala Besar). Hal ini tentunya menimbulkan dampak yang sangat signifikan, terutama pada kebiasaan masyaraka. Penulis melakukan penelitian ini pada warga Graha Rancamanyar Baleendah Kabupaten Bandung hal ini merujuk kepada data yang diperoleh dari Pemerintah Provinsi Jawa Barat bahwa pelanggaran terbanyak dalam masa pemberlakuan Adaptasi Kebiasaan Baru adalah Kabupaten Bandung. Penelitian ini dilakukan melalui pendekatan kualitatif. Metode ini memungkinkan peneliti mengkaji interaksi sosial subjek melalui wawancara mendalam. Melalui kajian komunikasi lintas budaya ini akan memberikan pemahaman dan gambaran kepada masyarakat dalam menghadapi permasalahan gegar budaya (culture shock).
\end{abstract}

Kata kunci:Gegar Budaya (Culture Shock); Adaptasi Kebiasaan Baru (AKB); Pandemi Covid 19

\section{Pendahuluan}

Adanya pandemi covid-19 mengakibatkan segala kehidupan global berubah drastis. Segala pekerjaan dilakukan dari rumah. Bahkan di beberapa daerah menerapkan PSBB (Pembatasan Sosial Berskala Besar ). Hal ini tentunya menyebabkan dampak yang sangat signifikan, terutama di kebiasaan warga. Adanya protokol kesehatan yang harus dijalankan oleh setiap individu meliputi 3M (memakai masker, menjaga jarak, dan mencuci tangan) bukan hal mudah untuk dilakukan. Masih banyak pelanggaranpelanggaran dalam implementasi protokol kesehatan tersebut.Dari data yang diperoleh dari Satgas Covid 19 Provinsi Jawa Barat melalui laman ayobandung.com, tercatat pelanggaran protokol kesehatan per 29 Agustus 2020 sebanyak 590.858 kasus 
pelanggaran. Adapun daerah di Jawa Barat yang menyumbang kasus pelanggaran terbesar ialah Kabupaten Bandung dengan 499.898 pelanggaran. Selain Kabupaten Bandung, Kota Bandung juga tercatat menyumbang kasus pelanggaran yang tinggi, yakni sebesar 3.031 kasus.

Selain Protokol kesehatan, hal lain yang berkaitan dengan adaptasi kebiasaan baru adalah pekerjaan yang umumnya dilakukan di luar tempat tinggal / ditempat kerja masing-masing, sekarang wajib mengikuti aturan WFH (Work From Home). Pendidikan yang seharusnya dilaksanakan di sekolah, sekarang menjadi pembelajaran daring (dalam jaringan) atau disebut juga home learning. Hal lain yang bisa kita jumpai yaitu pemberlakuan penggunaan masker setiap keluar tempat tinggal, dan harus mencuci tangan setelah bepergian. Begitupula pekerjaan seperti pedagang di pasar mulai dibatasi sebab mengikuti aturan untuk menghindari kerumunan.

Keluhan dan merasa frustasi dengan keadaan tidak jarang hal ini terjadi dalam sebuah perubahan kebiasaan. Adaptasi Kebiasaan Baru (AKB) dalam pandemic covid 19 ini, diberlakukan pembelajaran secara daring atau online jarak jauh, hal ini juga menjadi keluhan dari orang tua karena merasa kewalahan dalam mendampingi anak belajar online yang sebelumnya tidak dilakukan. Begitupula dengan anak yang kurang fokus dan tidak terbiasa belajar di rumah karena tidak dapat berinteraksi dengan temannya. Para pekerja harian yang kehilangan pekerjaan karena aturan menghindari kerumunan, serta masih banyak lagi keluhan yang dirasakan oleh warga.

Rasa frustrasi itu muncul dari ketidakmampuan untuk menyesuaikan diri dengan kebiasaan yang baru. Hal inilah yang dinamakan fenomena gegar budaya (culture shock) (Intan, 2019). Gegar budaya (culture shock) ialah istilah yang digunakan untuk mendeskripsikan perasaan terkejut, gelisah, keliru yang dirasakan bila seseorang bersentuhan dengan kebudayaan yang berlainan sama sekali, seperti saat berada di negara asing. Dalam (Samovar, Porter, \& McDaniel, 2010, p. 475) culture shock ialah mental yang berasal dari transisi terjadi saat satu lingkungan kiri yang ia tahu untuk datang serta tinggal pada lingkungan yang baru serta menemukan bahwa pola sikap Anda yang sebelumnya tidak efektif Jika Anda harus berlaku dalam lingkungan yang baru. Tanda-tanda tersebut meliputi seribu satu cara yang dilakukan dalam mengendalikan diri sendiri pada menghadapi situasi sehari-hari.

Begitupula yang dirasakan sebagian warga masyarakat Rancamanyar Baleendah Kabupaten Bandung di masa pandemi covid-19. Tinggal di wilayah sendiri bagaikan berada di wilayah asing, karena pola kehidupan yang sangat berbeda dengan sebelumnya. Perasaan ini timbul akibat adanya perbedaan dan kesukaran dalam beradaptasi dengan budaya baru. Gegar budaya bisa meliputi aspek yang ada pada kehidupan sehari-hari seperti makanan, cara berpakaian, harga barang, kebiasaan, dan lain sebagainya. Semakin tidak sama budayanya, semakin besar pengaruh yang disebabkan.jika kondisi ini masih terus dirasakan oleh sebagian besar warga, maka 
bisa mengakibatkan akibat yang kurang baik untuk kelangsungan hidup kedepannya. oleh sebab itu, terdapat beberapa hal yang bisa dilaksanakan oleh warga untuk mengatasi fenomena gegar budaya (culture shock) di masa pandemi covid-19.

\section{Metode Penelitian}

Penelitian ini memakai pendekatan penelitian kualitatif dimana penelitian kualitatif sebagai metode ilmiah tak jarang digunakan dan dilaksanakan oleh gabungan peneliti dalam bidang ilmu sosial, serta kajian yang peneliti lakukan sangat kental dengan bidang sosial. Penelitian kualitatif dilaksanakan buat menciptakan pengetahuan melalui pemahaman dan penemuan. Pendekatan penelitian kualitatif ialah suatu proses penelitian serta pemahaman yang sesuai pada metode yang mengkaji suatu fenomena social serta persoalan manusia. Fenomena sosial yang terjadi saat ini yang peneliti lakukan berkaitan dengan dampak sosial dengan adanya pandemic covid 19

Menurut (Sugiyono, 2015, p. 9) Metode penelitian kualitatif adalah metode yang berdasarkan pada filsafat postpositivisme, sedangkan untuk meneliti pada objek alamiah, dimana peneliti adalah sebagai instrumen kunci, teknik pengumpulan data dilakukan dengan cara triangulasi (gabungan). Analisis data bersifat induktif atau kualitatif, dan hasil penelitian lebih menekankan makna daripada generalisasi.

Dalam pandangan (Moleong, 2019, p. 9), Penelitian kualitatif adalah penelitian yang bermaksud untuk memahami fenomena tentang apa yang dialami oleh subjek penelitian misalnya perilaku, persepsi, motivasi, tindakan dan lain-lain secara holistik dan dengan cara deskripsi dalam bentuk kata-kata dan bahasa, pada suatu konteks khusus yang alamiah dan dengan memanfaatkan berbagai metode alamiah.

\section{Hasil dan Pembahasan}

\section{Hasil}

Berdasarkan hasil wawancara dengan beberapa informan dan observasi di lapangan mengenai adaptasi kebiasaan baru dalam masa pandemic covid 19 ini, penulis melihat adanya suatu proses kesadaran warga Graha Rancamanyar dalam memasuki masa adaptasi kebiasaan baru tersebut, meskipun dalam proses adaptasi tersebut perlu melalui berbagai tahapan. Membiasakan kebiasaan yang sudah terbentuk dalam tatanan kehidupan sehari-hari dan sudah menjadi habit sangat tidak mudah untuk dirubah, perlu adanya persuasi atau tindakan represi dari pemerintah maupun pihak-pihak terkait agar proses kebiasaan tersebut bisa dilakukan. Adapuntahapan yang paling kursial dalam proses adaptasi kebiasaan baru tersebut adalah tahapan dalam menghadapi gegar budaya (Culture shock). 
Warga masyarakat Graha Rancamanyar Kabupaten Bandung dalam masa pandemi covid-19 yang telah berlangsung beberpa bulan ini tidak terlepas dari imbas pandemic covid tersebut dan harus membiasakan dengan kebiasaan baru yang telah diberlakukan. Dalam menghadapi adaptasi kebiasaan baru tersebut warga Graha Rancamanyar mengalami pula gegar budaya (culture shock). Penerapan Protokol kesehatan yang mengharuskan setiap warga melakukan 3 M (Memakai Masker, Mencuci Tangan dan Menjaga Jarak), serta munculnya Istilah-isitlah baru dalam masa pandemic tersebut seperti lockdown, work from home, study from home, video conference, PSBB, Adaptasi Kebiasaan Baru (AKB) dan webinar menjadi istilah baru yang kemudian menjadi familiar di kalangan warga Graha Rancamanyar. Kehidupan sosial warga mengalami perubahan yang sangat signifikan, budaya baru muncul dan memaksa warga untuk masuk ke dalam budaya baru tersebut.

\section{Pembahasan}

Adaptasi kebiasaan baru seperti bekerja dari rumah (work from home) atau belajar dari rumah (study from home), kemudiankeharusan mematuhi protokol kesehatan tak ayal banyak orang yang mengalami "gegar budaya". Kita dipaksa untuk mempergunakan masker ketika berada diluar lingkungan rumah, mencuci tangan dan menjaga jarak ketika berkomunikasi. Dalam bidang lain kita juga dipaksa harus mengikuti alur perkembangan kebiasaan baru dengan mengunduh dan menggunakan berbagai macam aplikasi atau program yang dapat digunakan untuk menunjang berbagai kegiatan dari rumah tersebut. Untuk dapat melakukan rapat secara online misalnya kita harus membiasakan diri dengan aplikasi Zoom, Google Meet, Google Hangouts, atau Skype yang telah lebih dulu populer.

Keterpaksaan untuk tetap tinggal di rumah, ditunjang perkembangan teknologi dan media baru yang revolusioner, telah membuat kita secara suka rela memasuki budaya baru. Bekerja, belajar, sekolah, kuliah, seminar, rapat, belanja, memesan makanan, dan bahkan menonton film atau pertunjukan seni dan konser musik terpaksa di lakukan dari rumah dengan memanfaatkan dunia maya (dunia siber).Kebiasaankebiasaan yang secara otomatis kita jalani setiap hari tersebut pada akhirnya harus digantikan dengan bekerja dari rumah, rapat online dari rumah, memesan makan siang atau kopi favorit dari rumah, sampai menonton film pun dilakukan dari rumah.

Demikian pula dengan warga masyarakat Rancamanyar Baleendah Kabupaten Bandung, saat memasuki budaya baru (budaya asing), warga seperti akan kehilangan 'petunjuk budaya' yang telah mereka milikisebelumnya. Layaknya ikan yang keluar dari air, warga yang memasukisuatu budaya baru,maka warga tersebut harus melakukan penyesuaian dengan kebiasaan baru lingkungan tempat tinggalnya. Dalam menghadapi budaya baru tersebut ada beberapa tahapan agar bisa melaluiCulture shocksehingga proses adaptasi dalam kebiasaan baru tersebut akan segera dilalui.

Komunikasi merupakan fungsi dari budaya. Oleh karena itu, perilaku komunikasi adalah cerminan budaya asal dari partisipasinya. Seseorang menggunakan 
simbol, baik berupa kata-kata maupun gerakan tubuh dalam berkomunikasi. Ketika kedua hal ini digunakan dalam berkomunikasi dengan orang yang memiliki perbedaan budaya, maka hal ini akan menjadi suatu permasalahan (Kartika, 2013). Dalam komunikasi Lintas Budaya ketika proses adaptasi pada budaya atau kebiasaan baru berlangsung akan timbul gegar budaya (culture shock) istilah ini pertama kali diperkenalkan oleh Antropologis bernama Oberg pada tahun 1950-an. Oberg mendefenisikan culture shock sebagai kegelisahan yang muncul karena kehilangan semua lambang dan simbol yang familiar dalam hubungan sosial, termasuk di dalamnyacara-cara yang mengarahkan kita dalam situasi keseharian, misalnya bagaimana untuk memberi perintah, bagaimana membeli sesuatu, kapan dan di mana kita tidak perlu merespon (Samovar, Porter, McDaniel, \& Roy, 2014, pp. 14-15). Gegar budaya, merupakan sebuah fenomena emosional yang disebabkan oleh terjadinya disorientasi kognitif seseorang sehingga menyebabkan gangguan pada identitas (Kevinzky, 2011). Menurut (Abbasian \& Sharifi, 2013, pp. 154-159) mengemukakan bahwa gegar budayamerupakan reaksi emosional terhadap perbedaan budaya yang tak terduga dan kesalahpahaman pengalaman yang berbeda sehingga dapat menyebabkan perasaan tidak berdaya, mudah marah, dan ketakutan akan ditipu, dilukai, ataupun diabaikan.

Gegar Jika dilihat dari tingkatan-tingkatan culture shock yang dikemukakan dalam Intercultural Communication Between Cultures (Samovar et al., 2014, pp. 477478) digambarkan dalam bentuk kurva U sehingga disebut U-Curve, maka peneliti membuat pembahasan sebagai berikut :

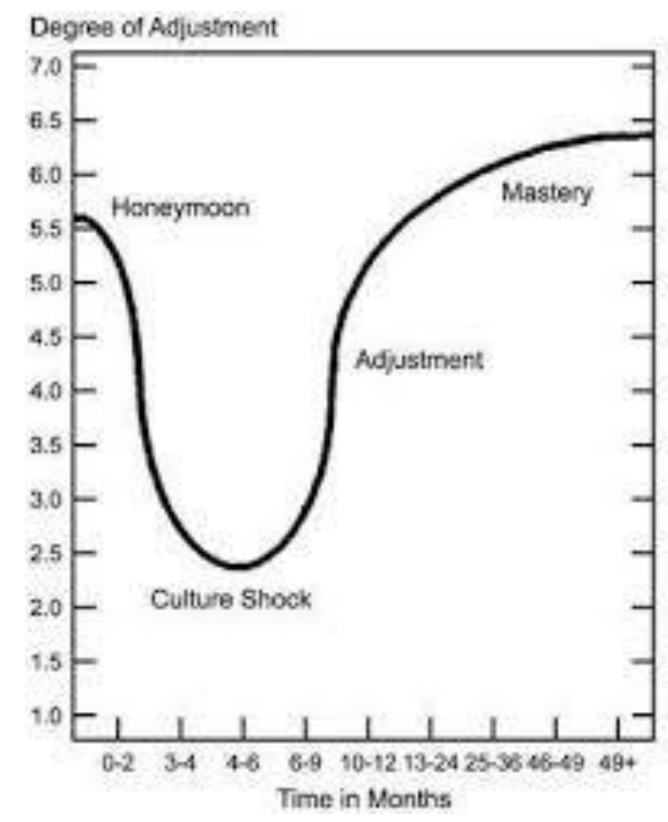




\section{Honeymoon Stage}

Pada tahap ini individu yang baru saja memasuki budaya baru merasa ada sesuatu yang berbeda dan antusias dengan keadaan yang dia alami. Perbedaan antara budaya lama dan budaya baru tidak dirasakan karena kekaguman yang dia rasakan. Hal ini dialami pula oleh warga Graha Rancamanyar,pada awal pandemic warga masyarakat Graha Rancamanyar dipaksaharus menambah wawasan mengenai wabah pandemic covid 19, mulai dari penyebaran, pencegahan sampai pengobatan melalui sosialisasi yang dilakukan oleh pihak pemerintah setempat.

Cara terbaik yang lain yang dilakukan oleh sebagian warga Graha Rancamanyar adalah dengan membaca panduan tentang apa dan bagaimana covid 19 tersebut, bertanya kepada orang yang lebih paham, browsing di internet, dan satu hal yang dilakukan oleh sebagian warga Graha Rancamanyar adalah tidak memandang atau membayangkan covid 19 ini dari satu sisi saja baik sisi positif atau negative,sebab bila hal itu dilakukan yaitu memandang pada satu sisi saja maka akan terjebak dalam halusinasi dan kesalahpahaman.Kemudian untuk mencegah penyebaran covid 19, warga Graha Rancamanyar melakukan pekerjaan dan pembelajaranyang sifatnya harus di rumah dengan mempergunakan media secara online sehingga warga dituntut untuk mencoba dan memahami bagaimana mempergunakan media tersebut.

\section{Rejection or Regression Stage}

Dalam tahap ini rasa letih dari tahap sebelumnya mulai dirasakan secara fisik. Warga Graha Rancamanyar yang mengalami tahap ini mulai merasakan perbedaan dari budaya baru yangdihadapi.Rasa bosan di rumah terus menerus, hilangnya sumber pendapatan, kehilangan motivasi kerja. Alasannya cukup beragam, misalnya suasana kerja tidak seperti yang diharapkan, suasana rumah tidak seperti kantor, terdistraksi oleh media sosial dan hiburan lainnya.Biaya listrik dan internet akan membengkak lantaran pemakaian terus-menerus. Untuk anak-anak yang belajar dirumah pembelajaran kurang efektif karena hanya memaksimalkan teknologi yang tidak begitu efektif dalam menyampaikan pelajaran, kesulitan dalam hal melakukan konsultasi dengan guru terutama untuk pelajaran yang dianggap membutuhkan penjelasan dan pemahaman lebih mendalam, misalnya matematika.

Orang tua yang merasa lelah karna harus mendampingi anaknya dalam belajar dan satu sisi orang tua juga banyak yang tidak paham bagaimana cara menyampaikan pemahaman kepada anak sebab tidak memiliki kemampuan didaktik dan metodik dalam cara mengajar mendampingi anak. Pada tahap ini timbul perasaan rindu akan kembali segala sesuatunya berjalan normal seperti biasa, berinteraksi dengan teman-teman baik di kantor maupun di sekolah karena ekspektasi dalam budaya baru yang berbeda. Hal ini membuat pemikiran bahwa budaya asal lebih baik daripada budaya baru yang dia tinggali. 


\section{Adjustment or Negotiation Stage}

Tahap ini adalah saat dimana warga Graha Rancamanyar mulai secara perlahan beradaptasi dengan kebiasaan barunya. Warga Graha Rancamanyar masih menyadari perbedaan antara kebiasaan lama dan kebiasaan barunya, tetapi dengan panjangnya masa pandemic covid 19 ini maka menjadi suatu keharusan yang akan diikuti dan dibiasakan dalam tatanan kehidupan sehari-hari. Meskipun dampak negative dari pelaksanaan adaptasi kebiasaan baru ini sangat dirasakan akan tetapi sebagian warga Graha Rancamanyar juga melihat pada sisi kebiasaan positive dari dampak pandemic covid 19 ini. Beberapa hal yang dilakukan oleh sebagian warga Rancamanyar dalam menghadapi tahap ini yaitu:

Pertama, berpikir positif, dengan membangun paradigma positif Warga Graha Rancamanyar mengenai wabah ini untuk tidak dianggap sebagai suatu bencana, akan tetapi lebih pada pembelajaran pada diri kita untuk selalu menjaga kebersihan, lebih peduli dengan kesehatan, serta mempunyai lebih banyak waktu untuk membangun kedekatan dengan keluarga. Selain itu, sisi positif yang dapat kita lihat yaitu adanya kerjasama seluruh warga negara di berbagai belahan dunia, memicu solidaritas antar sesama, kualitas udara membaik karena berkurangnya tingkat penggunaan kendaraan akibat isolasi mandiri yang harus dilakukan, dan masih banyak hal positif yang dapat kita lihat dari adanya wabah virus covid-19. Dengan berpikir positif, maka warga Graha Rancamanyar akan hilang rasa cemasnya akibat perubahan kebiasaan dan perlahan akan mulai berkurang sehingga dapat menjalani kehidupan yang lebih baik.

Kedua, melakukan kegiatan positif di rumah. Sebagian besar warga Graha Rancamanyar dalam menghindari rasa bosan di rumah, ada yang melakukan beberapa kegiatan positif yang juga dijadikan kesempatan untuk mengembangkan potensi yang ada dalam diri warga tersebut. Misalnya bagi ibu-ibu yang memiliki hobi memasak dan seni, sudah mencoba resep masakan baru untuk para anggota keluarga, dan menyalurkan hobi seni dengan membuat kerajinan tangan. Para pemuda pecinta musik melakukan dan berlatih bermain musik serta menciptakan beberapa lagu. Warga Graha Rancamanyar yang memiliki bakat berjualan yang terbiasa jualan secara langsung, kini beralih ke sistem penjualan online. Serta masih banyak lagi kegiatan positif yang dapat di lakukan oleh warga Graha Rancamanyar untuk menghindari kebosanan dan menghilangkan perasaan cemas selama masa pandemi covid-19.

Ketiga, sebagian besar warga Graha Rancamanyar menerapkan pembelajaran yang menarik. Hal ini dapat dilakukan dengan cara bekerjasama guru ataupun orang tua siswa. Untuk menghindari kebosanan anak dalam melaksanakan pembelajaran online, anak dapat diberikan kuis online melalui aplikasi tertentu yang berisikan beberapa soal mengenai materi. Hal ini dapat memacu semangat belajar anak serta menghindari kebosanan. Kemudian memberikan ruang untuk anak belajar secara langsung seperti membuat suatu karya berupa poster bertemakan covid-19. Serta masih banyak lagi hal yang dapat dilakukan guru atau pun orang tua yang ada pada sebagian besar warga Graha Rancamanyar untuk meningkatkan ketertarikan belajar anak. 


\section{Mastery Stage}

Mastery stage adalah tahap dimana warga Graha Rancamanyar diharapkan dapat menguasai adaptasi kebiasaan baru tersebut, sebab tidak banyak warga yang bisa mencapai tahap ini, hal ini juga tidak lepas dari pengaruh pada tahap Rejection or Regression Stage.masih melekat dan masih juga ada anggapa bahwa pandemic covid 19 ini adalah sebuah rekayasa

Reaksi warga Graha Rancamanyar terhadap culture shock bervariasi, tergantung dari pengalaman warga tersebut dalam menghadapinya. Meskipun tidak banyak, ada juga warga yang tidak bisa hidup dalam adaptasi kebiasaan barunya. Culture shock, tidak selalu akan terjadi pada warga yang hanya melakukan kebiasaan barunya hanya sesaat, melainkan akan terjadi pula dengan warga yang harus setiap hari menjalani kehidupan baru dan benar-benar mengatasi permasalahan hidupnya di sana.

Contoh sederhana dari culture shock, yakni dulunya warga Graha Rancamanyar memiliki kebiasaan cuci tangan hanya dilakukan sebelum makan. Kini berbeda, bahkan seorang warga yang hendak belanja di warung tetangga-pun diharuskan cuci tangan oleh pemiliknya. Warga yang biasanya memakai masker hanya ketika mempergunakan kendaraan di jalan, atau sedang sakit, maka sekarang seperti wajib pakai masker ketika berada di luar rumah.Apalagi jaga jarak, yang dulunya identik dengan anti-sosial, justru kini menjadi hal yang lumrah bagi warga Graha Rancamanyar, bahkan untuk kegiatan ibadahpun sampai harus memperhatikan hal tersebut.

Namun demikian tidak semua warga akan bisa menerima adaptasi kebiasaan baru tersebut dimana ada sebagian warga Graha Rancamanyar yang belum menyadari perlunya perubahan perilaku karena individu tersebut merasa kebiasaan yang dilakukan merupakan normalitas yang baik-baik saja. Sehingga perlu sebuah tahapan kontemplasi, dimana warga pada tahapan ini perlu menyadari untuk berubah. Bisa dikatakan, shock culturewarga karena pandemic Covid-19 berada tahapan ini.Tahapan ini benar-benar membuat warga mulai merasa bahwa kebiasaan lamanya perlu direnungkan kembali untung-ruginya.Pada tahap ini, proses edukasi yang kuat sangat dibutuhkan, karena upaya menemukan 'belief' guna membangun motivasi perubahan sangat dibutuhkan pada kondisi ini.

Jika pada tahap tadi dibangun proses edukasi dari tidak tahu menjadi tahu atau sadar, maka pada tahapan berikutnya adalah upaya mendorong warga agar yang tahu menjadi menjadi mau untuk melakukan perubahan.Selanjutnya, tahapan berikutnya adalah tindakan. Proses edukasi juga harus tetap jalan pada tahapan ini, namun metodenya berbeda. Kita lebih fokus pada merubah perilaku warga dari seseorang yang mau menjadi mampu untuk berubah. Adaptasi kebiasaan Baru, baru akan hadir pada bagian akhir, yakni pada tahap maintenance atau pemeliharaan kebiasaan baru.Tindakan baru yang dilakukan berulang-ulang akan menjadi kebiasaan baru. Konsistensi membangun kebiasaan baru ini sangat berat, oleh karena itu proses penguatan kapasitas individu melalui edukasi, dan didukung dengan pengkondisian lingkungan yang memadai untuk memungkinkan masyarakat mempertahankan kebiasaan barunya. Oleh 
sebab itu, terjadinya culture shockpada warga masyarakat Graha Rancamanyar di saat pandemic Covid-19, terdapat peluang untuk mendorong perubahan perilaku hidup sehat.Seperti membangun budaya perilaku hidup bersih dan sehat, aktivitas fisik yang rutin serta konsumsi pangan yang sehat guna meningkat imunitas. Namun di lain sisi, warga juga tengah menghadapi tantangan yang tidak sedikit di saat culture shock seperti ini, seperti perlunya penguatan literasi publik, manajemen stres, manajemen kegawatdaruratan, hingga penguatan modal sosial agar proses menuju Adaptasi Kebiasaan Baru (AKB) bisa diwujudkan.

\section{Kesimpulan}

Pandemi Covid-19 yang telah berlangsung selama beberpa bulan ini menciptakan kebiasaan baru di dalam kehidupan masyarakat. Protokol kesehatan yang mengharuskan setiap warga melakukan 3 M (Memakai Masker, Mencuci Tangan dan Menjaga Jarak), kegiatan yang tidak seperti biasanya dan penggunaan media dalam berkomunikasi tidak seperti biasanya yaitu dengan melalui media online, sehingga kehidupan sosial mengalami perubahan yang sangat signifikan, budaya baru muncul dan memaksa kita untuk masuk ke dalam budaya baru tersebut.Adaptasi kebiasaan baru seperti tersebut tak ayal banyak yang mengalami "gegar budaya".Hal ini dialami pula oleh warga Graha Rancamanyar yang terkena imbas dari permasalahan yang sudah mengglobal ini. Dalam proses mencapai Adaptasi Kebiasaan Baru tersebut warga Rancamanyar juga mengalami beberapa tahap culter shock tahap pertama adalah tahap Honeymoon Stage Pada tahap ini warga Graha Rancamanyar baru saja memasuki budaya baru merasa ada sesuatu yang berbeda yang dialami. Tahap Kedua adalah Rejection or Regression Stage Dalam tahap ini rasa letih dari tahap sebelumnya mulai dirasakan secara fisik. Tahap ketiga adalah tahap Adjustment or Negotiation StageTahap ini adalah saat dimana warga Graha Rancamanyar mulai secara perlahan beradaptasi dengan kebiasaan barunya. Dan tahap terakhir adalah tahap Mastery Stageyaitu tahap dimana warga Graha Rancamanyar diharapkan dapat menguasai adaptasi kebiasaan baru tersebut, sebab tidak banyak warga yang bisa mencapai tahap ini, hal ini juga tidak lepas dari pengaruh pada tahap Rejection or Regression Stage

Terjadinya culture shockpada warga masyarakat Graha Rancamanyar di saat pandemic Covid-19, terdapat peluang untuk mendorong perubahan perilaku hidup sehat.Seperti membangun budaya perilaku hidup bersih dan sehat, aktivitas fisik yang rutin serta konsumsi pangan yang sehat guna meningkat imunitas. Namun di lain sisi, warga juga tengah menghadapi tantangan yang tidak sedikit di saat culture shock seperti ini, seperti perlunya penguatan literasi publik, manajemen stres, manajemen kegawatdaruratan, hingga penguatan modal sosial agar proses menuju Adaptasi Kebiasaan Baru (AKB) bisa diwujudkan. 
Suhaeri

\section{BIBLIOGRAPHY}

Abbasian, F., \& Sharifi, S. (2013). The Relationship between Culture Shock and Sociolinguistic Shock: A Case Study of Non-Persian Speaking Learners. Journal of Social Science Research, 1(6), 154-159.

Intan, T. (2019). GEGAR BUDAYA DAN PERGULATAN IDENTITAS DALAM NOVEL UNE ANNÉE CHEZ LES FRANÇAIS KARYA FOUAD LAROUI. Jurnal Ilmu Budaya, 7(2), 163-175.

Kartika, T. (2013). Komunikasi Antar Budaya (Definisi, Teori dan Aplikasi Penelitian). Lampung: Lembaga Penelitian Universitas Lampung.

Kevinzky, M. H. (2011). Proses dinamika komunikasi dalam menghadapi Culture Shock pada adaptasi mahasiswa perantauan (Kasus adaptasi mahasiswa perantau di UNPAD Bandung).

Moleong, L. J. (2019). Metodologi penelitian kualitatif.

Samovar, L. A., Porter, R. E., \& McDaniel, E. R. (2010). Komunikasi Lintas Budaya.(IM Sidabalok, Trans.). Jakarta: Salemba Humanika.

Samovar, L. A., Porter, R. E., McDaniel, E. R., \& Roy, C. S. (2014). Intercultural communication: A reader. Cengage Learning.

Sugiyono, P. (2015). Metode penelitian kombinasi (mixed methods). Bandung:

Alfabeta. 